\title{
Enhancement in Selectivity of Coking Coal Flotation by Ultrasound Simultaneous Treatment
}

\author{
Yijiang Li, Wencheng Xia*, Yuqiang Mao, Guangxi Ma, Yaoli Peng, Guangyuan Xie, Yanfeng Li \\ School of Chemical Engineering and Technology, China University of Mining \& Technology, Xuzhou, Jiangsu \\ 221116, China \\ Email: xiawencheng@cumt.edu.cn
}

\begin{abstract}
The influence of ultrasound simultaneous treatment on coking coal flotation were investigated by adding ultrasound to the pulp zone. The flotation results showed ultrasound simultaneous flotation (USF) produced the clean coal of lower ash content compared with conventional flotation $(\mathrm{CF})$. Moreover, the combustible recovery rate of USF was higher than that of $\mathrm{CF}$. Scanning electron microscope found that the ultrasound could reduce the high-ash fine slime coated on coal surface. Particle size distribution results showed the ultrasound simultaneous treatment increased the recovery of coarse coal. The coal surface oxidation was found by the X-ray photoelectron spectroscopy of coal surface with/without ultrasound treatment. The negative impact of ultrasound on the surface oxidation was much less than the positive effect of ultrasound on reducing the slime coating on coal surface and increasing the aggregates of the bubbles. It is concluded that USF of coking coal has a higher selectivity than $\mathrm{CF}$.
\end{abstract}

Keywords: coal flotation; ultrasound; selectivity; scanning electron microscope; X-ray photoelectron spectroscopy.

\section{Introduction}

Coking coal is the mainly used to produce coke as raw material in the metallurgical industry [1,2]. Before the utilization, it is necessary to remove the minerals from the coal by flotation and gravity separation [3]. At present, flotation is the main ways to effectively remove fine gangue particles from fine coal particles $[4,5]$. The flotation mechanism relies on the physical and chemical differences between the coal and gangue surface, while the hydrophobic coal particles are carried to the froth layer and the gangue particles are left in the pulp. Coking coal have great floatability due to its high degree of metamorphism. Flotation can get a high clean coal yield when the dosage of collector is low. However, a lot of high-ash slime can coat on clean coal surface during flotation, which pollutes the clean coal and decreases the grade of clean coal products $[6,7]$. Thus, it is particularly important to use technical means to effectively reduce the ash content of coal. Xia et al. [8] discovered that the mixture collector of nano-carbon particles and n-dodecane can increase the yield of coking coal by about $1 \%$ and also decrease the ash content of clean coal. Li et al.[9] used soybean oil as a sustainable flotation collector to not only increase the clean coal yield but also reduce the clean coal ash content. In addition, the application of flotation column in coal separation can effectively reduce the clean coal ash content [10,11]. Ultrasound simultaneous flotation (USF) is also used in low-rank coal flotation as an emerging high-efficiency flotation method in recent years [12-14]. Mao et al. [13] found that ultrasound evidently improved the flotation of fine lignite particles and the water recovery. Ozkan et al.[15] found that USF can not only increase the recovery rate of hard coal, but also reduce the ash content of clean coal. In addition, the effect of ultrasonic treatment on the particle size, shape and ash content of lignite was studied through Mao et al [16]. Chen et al.[17] found that ultrasound pretreatment can not only clean the slime on the coking coal surface, but also enhance the dispersion of collector in pulp. There are few studies on the influence of ultrasound on the coking coal flotation and its deashing performance. Therefore, this study innovatively studied the enhanced selectivity mechanism of coking coal flotation through adding ultrasound to the pulp zone.

This paper took coking coal as sample and investigated the influence of USF on the coking coal. Scanning electron microscope (SEM) was used to observe the influence of ultrasound on the slime coated on coal surface. X-ray photoelectron spectroscopy (XPS) was used to determine the influence of ultrasound on the 
coking coal surface properties. The laser particle size was used to analysis the influence of ultrasound on the clean coal particle size distribution.

\section{Experiment}

\subsection{Coal Samples}

The samples used for the work were taken from a coking coal preparation plant in Shanxi province, China. Table 1 shows the proximate analysis result of coal sample. Table 2 shows the result of coal size composition. The density fraction analysis of raw coal was shown in Table 3.

The screening test result of raw coal sample showed that the main size fraction was $0.5 \sim 0.25 \mathrm{~mm}$, followed by $<0.045 \mathrm{~mm}$. There were many coarse particles in the coal sample as well as high-ash slime. The high-ash slime were easy to cause entrainment in the froth layer, leading to the high clean coal ash content. Table 3 revealed the theoretical clean coal yield was about $68 \%$ with the ash content of $10 \%$ at about $1.57 \mathrm{~kg} / \mathrm{L}$.

Table 1. Proximate analysis of coking coal sample (air-dry basis)

\begin{tabular}{cccc}
\hline Moisture (\%) & Ash (\%) & Volatile (\%) & Fixed Carbon (\%) \\
\hline 0.45 & 24.16 & 24.49 & 50.90 \\
\hline
\end{tabular}

Table 2. Coal sample screening test results

\begin{tabular}{ccccc}
\hline \multirow{2}{*}{ Size Fraction $(\mathrm{mm})$} & Yield $(\%)$ & \multirow{2}{*}{ Ash $(\%)$} & \multicolumn{2}{c}{ Cumulative Undersize } \\
\cline { 4 - 5 } & & & Yield $(\%)$ & Ash $(\%)$ \\
\hline$\geq 0.500$ & 7.95 & 23.94 & 7.95 & 23.94 \\
$0.500-0.250$ & 37.47 & 23.87 & 45.42 & 23.88 \\
$0.250-0.125$ & 15.76 & 23.36 & 61.19 & 23.75 \\
$0.125-0.074$ & 10.82 & 23.33 & 72.01 & 23.69 \\
$0.074-0.045$ & 6.33 & 21.52 & 78.34 & 23.51 \\
$<0.045$ & 21.66 & 25.95 & 100.00 & 24.04 \\
\hline Total & 100.00 & 24.04 & & \\
\hline
\end{tabular}

Table 3. Coal sample float and sink test results

\begin{tabular}{ccccc}
\hline Gravity Range $(\mathrm{kg} / \mathrm{L})$ & \multirow{2}{*}{ Yield $(\%)$} & Ash $(\%)$ & \multicolumn{2}{c}{ Cumulative Floats } \\
\cline { 4 - 5 } & 21.32 & 2.05 & 21.32 & 2.05 \\
\hline-1.3 & 22.87 & 8.11 & 44.19 & 5.19 \\
$1.3-1.4$ & 17.04 & 16.98 & 61.23 & 8.47 \\
$1.4-1.5$ & 11.72 & 28.32 & 72.95 & 11.66 \\
$1.5-1.6$ & 7.63 & 36.99 & 80.58 & 14.06 \\
$1.6-1.7$ & 4.47 & 46.52 & 85.06 & 15.77 \\
$1.7-1.8$ & 14.94 & 72.14 & 100.00 & 24.19 \\
$\geq 1.8$ & 100.00 & 24.19 & & \\
\hline
\end{tabular}

\subsection{SEM and Laser Particle Size Tests}

The clean coal surface after coating with a layer of gold was analyzed by Quanta 250 SEM (FEI, USA) at a magnification of 1,000 .

Microtrac Inc S3500 laser particle size analyser (America) was applied to analyze the size distribution of clean coal particles. In order to disperse the coal particles effectively, coal particles were added to a 5 wt.\% aqueous solution of sodium hexametaphosphate and stirred by ultrasound treatment for 5 min. 


\subsection{XPS Tests}

The XPS analysis of the clean coal surface was carried out in an ultra-high vacuum (UHV) system with the surface analysis system (ESCALAB $250 \mathrm{Xi}$, America) at room temperature. The peak fitting was analyzed by XPS Peak fitting software.

\subsection{Flotation Experiments}

Flotation were operated in a $1.5 \mathrm{~L}$ flotation cell and the mass fraction of coal sample in pulp was $6 \%$. In addition, the impeller speed at $1800 \mathrm{rpm}$. The kerosene was used as collector at $200 \mathrm{~g} / \mathrm{t}$ coal. The secoctyl alcohol was used as frother at $80 \mathrm{~g} / \mathrm{t}$ coal.

Firstly, the coal and water were added into flotation cell and conditioned for $180 \mathrm{~s}$. Secondly, adding kerosene and stirring for $120 \mathrm{~s}$. Thirdly, adding sec-octyl alcohol and stirring for $30 \mathrm{~s}$. Finally, the air flow rate was $250 \mathrm{ml} / \mathrm{min}$ and the flotation froth was collected at 10s, 30s, 60s, 120s and 180s. The USF was consistent with CF. The difference was that the ultrasound probe was inserted into the pulp zone of flotation cell when the air was given during USF. Ultrasound power setting of $100 \mathrm{~W}$ was selected for USF tests. The clean coal and tailings were collected, dried, weighed and analyzed. The yield and ash content of clean coal were used to evaluate the effect in flotation behavior of coal with ultrasound treatment. The combustible recovery rate, yield and ash content were calculated from the following equation $[18,19]$ :

$$
\text { Combustible recovery rate }=\left[Y_{\mathrm{C}}\left(100-A_{\mathrm{C}}\right) / Y_{\mathrm{F}}\left(100-A_{\mathrm{F}}\right)\right] \times 100
$$

where $Y_{\mathrm{C}}$ is the yield of the clean coal (\%); $Y_{\mathrm{F}}$ is the yield of the feed (\%), 100\%; $A_{\mathrm{C}}$ is the ash content of the clean coal (\%); $A_{\mathrm{F}}$ is the ash content of the feed (\%).

$$
\begin{gathered}
Y_{\mathrm{C}}=\frac{W_{\mathrm{C}}}{W_{\mathrm{C}}+W_{\mathrm{T}}} \\
A_{\mathrm{C}}=\frac{W_{\mathrm{A}}}{W_{\mathrm{F}}}
\end{gathered}
$$

where $W_{\mathrm{C}}$ is the weight of the clean coal $(\mathrm{g}) ; W_{\mathrm{T}}$ is the weight of the tailings $(\mathrm{g}) ; W_{\mathrm{A}}$ is the residual ash weight after coal combustion completely $(\mathrm{g})$; $W_{\mathrm{F}}$ is the sample weight before combustion $(\mathrm{g})$.

\section{Results and Discussion}

\subsection{SEM and Laser Particle Size Results}

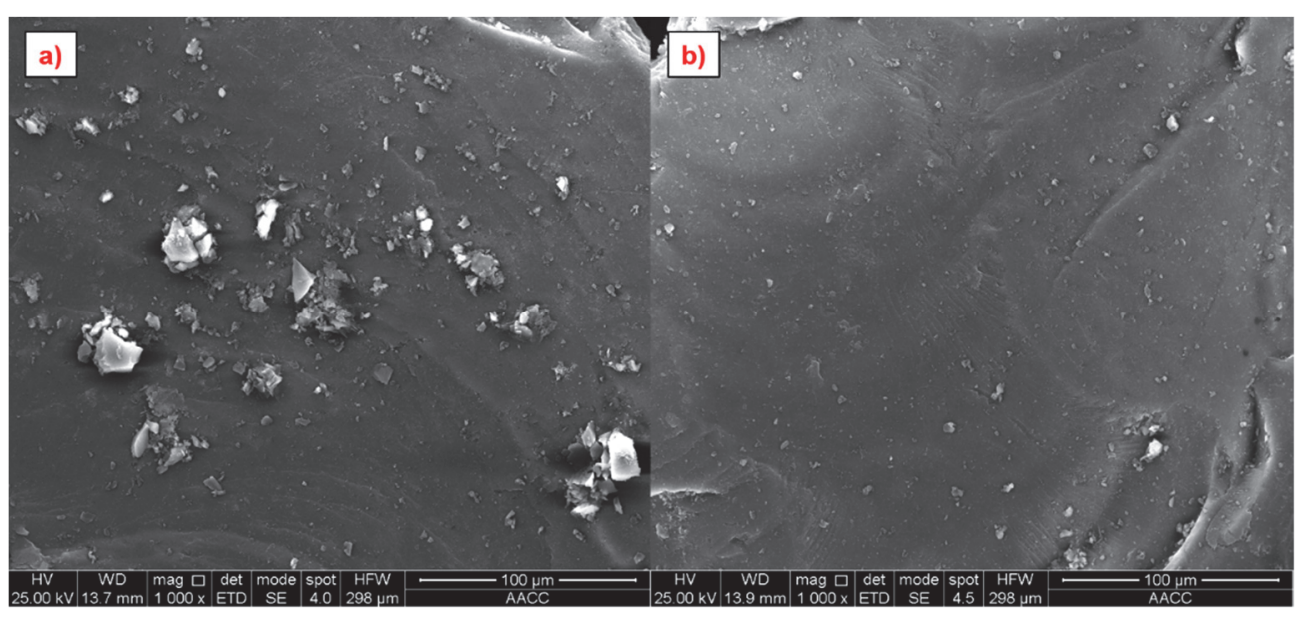

Figure 1. SEM results of the clean coal by conventional (a) and ultrasound simultaneous (b) flotation 
Figure 1 indicated the clean coal surface of CF has more coated slime particles than that of USF. It indicated that the ultrasound had a cleaning action on the coal surface. This behavior was beneficial to reduce the ash content of clean coal. Reducing the hydrophilic slime coated on the coal surface can indirectly increase the hydrophobicity of the coal in the flotation pulp, thereby increasing the adhesion probability between the coal and bubbles. Mao et al [20] also found that ultrasound have a strong cleaning effect on the lignite surface, resulting in the high yield and the low ash content of clean coal by USF. In addition, they found that the ultrasound can also reduce the high-ash slime coated on the lignite surface, which benefits the improving the adsorption of collector on lignite surface and improving the flotation recovery [13]. Therefore, USF can enhance the selectivity of coking coal flotation.

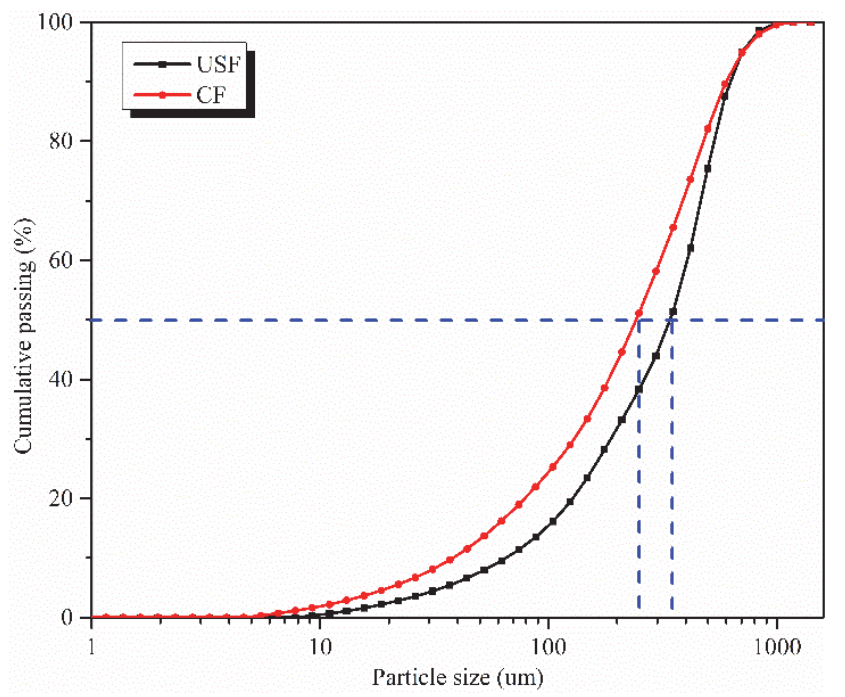

Figure 2. Laser particle size analysis results of clean coal produced by CF and USF

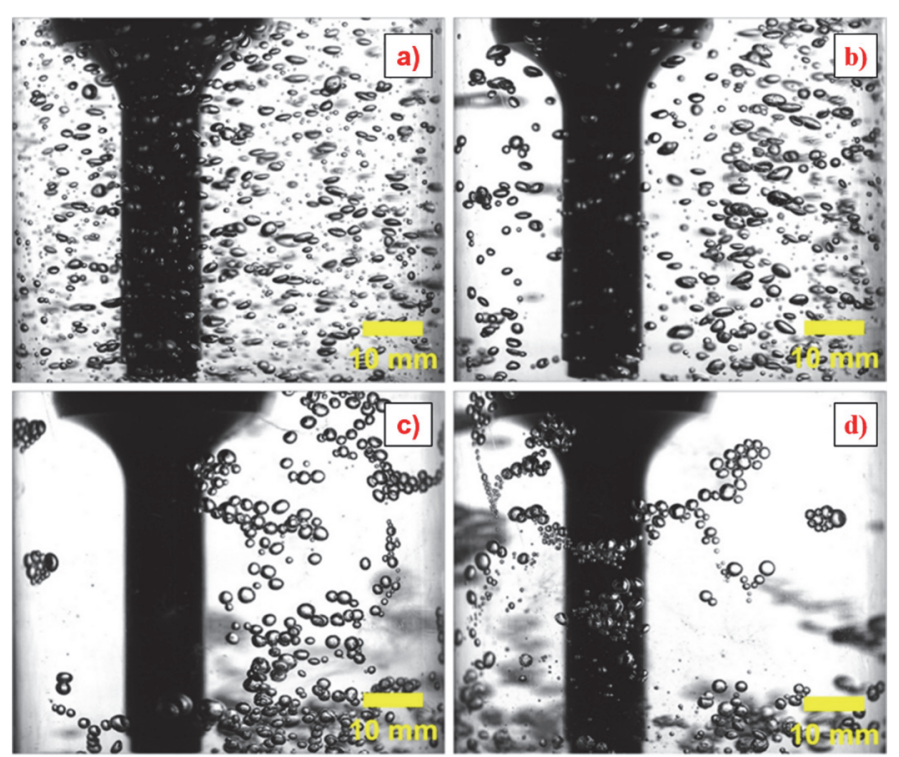

Figure 3. Pictures of the influence of ultrasound on bubble aggregates (a, 0 W; b, $20 \mathrm{~W}$; c, $110 \mathrm{~W}$; d, 200 W)[21].

Figure 2 illustrated size distribution analysis results of clean coal produced by CF and USF. The d50 of CF clean coal was $241 \mu \mathrm{m}$ and the d50 of the clean coal by USF was increased to $342 \mu \mathrm{m}$. It indicated that in the coking coal flotation, the addition of ultrasound was good for coarse coal particles to float. This is different from the results of Mao et al [13], the sample of their study were lignite with low hardness, 
while the samples used in this study were hard coking coal. Compared with lignite, ultrasound is not easy to break coking coal. As shown in Figure 3, Mao et al [21] found the addition of ultrasound during the flotation process was not only advantageous for the generation of large bubbles, but also for the aggregates or attraction of the bubbles. According to their finds, $100 \mathrm{~W}$ ultrasound can lead to the bubbles aggregate in the pulp in this study. These bubble aggregates had a greater carrying capacity than the single bubble and they can carry coarse coal particles into the froth layer, which enhances coarse coking coal flotation. The interaction between bubble aggregates contributed to drainage between the bubbles [22], and the high-ash slimes return to the pulp zone with the drainage, thereby enhancing the secondary enrichment of fine coal in the flotation froth. Therefore, the content of high-ash slimes was reduced effectively in the flotation clean coal.

\subsection{XPS Results}

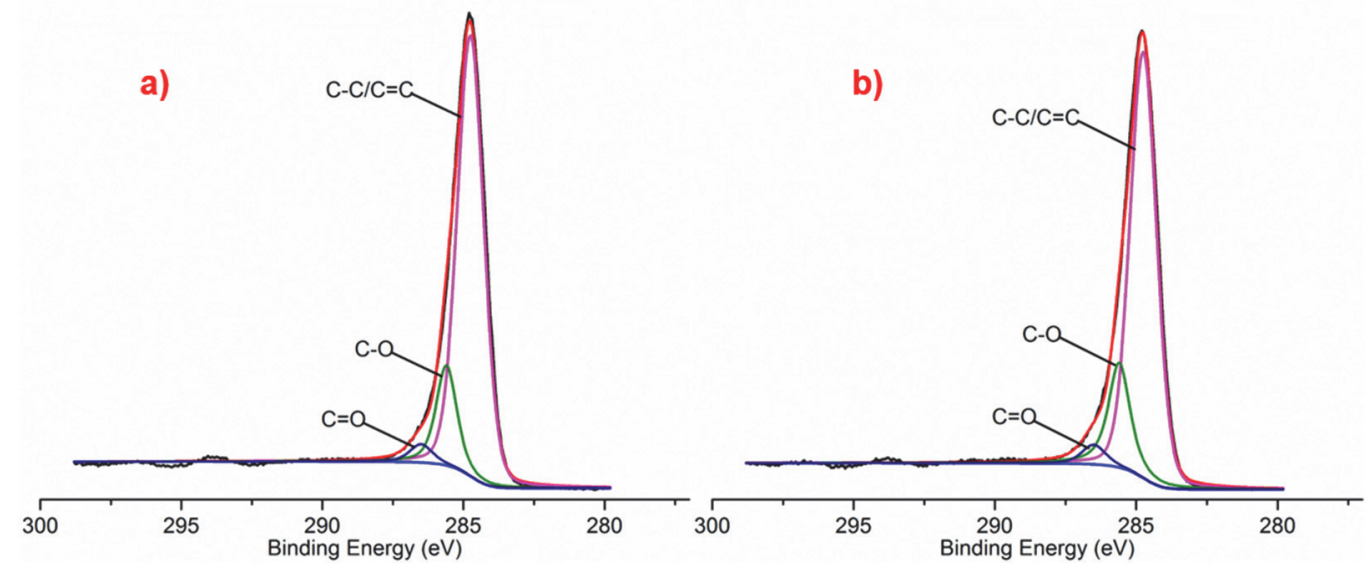

Figure 4. C1s peak of coal surface produced by a) conventional flotation and b) ultrasound simultaneous flotation

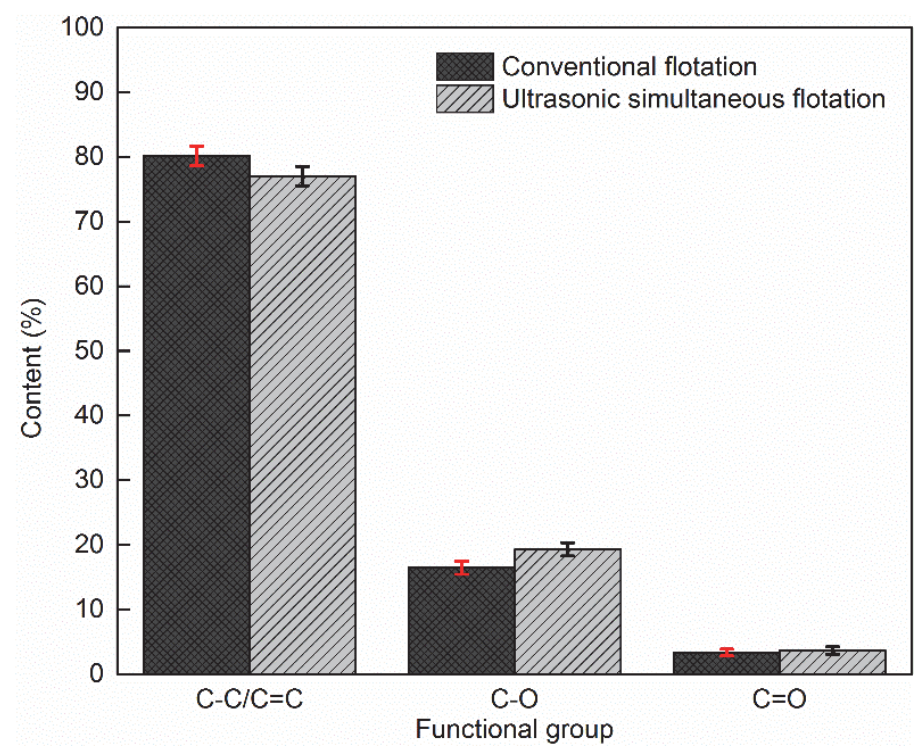

Figure 5. Functional group content of clean coal surface produced by conventional and ultrasound simultaneous flotation

Figure 4 and Figure 5 showed the C1s narrow energy spectrum results of clean coal surfaces by CF and USF. For the C1s, the peaks position at about $284.7 \mathrm{eV}, 285.4 \mathrm{eV}$ and $286.6 \mathrm{eV}$ correspond to the groups: 
$\mathrm{C}-\mathrm{C} / \mathrm{C}=\mathrm{C}, \mathrm{C}-\mathrm{O}$ and $\mathrm{C}=\mathrm{O}$ [23-26]. Figure 5 showed when the ultrasound was added in the flotation process, the content of $\mathrm{C}-\mathrm{C} / \mathrm{C}=\mathrm{C}$ on the clean coal surface was reduced a little compared to that without the ultrasound treatment, while the content of $\mathrm{C}-\mathrm{O}$ and $\mathrm{C}=\mathrm{O}$ increases a little. Which indicated that ultrasound had a slight oxidation effect on coking coal surface. Xu et al. [12] found that 20 minutes of ultrasound pretreatment increased the content of oxygen-containing functional groups on the surface of oxidized coal. They thought this is caused by the reoxidation of coal surface through ultrasound treatment. Although the ultrasound treatment time is short in this study, it is found that the reoxidation of coking coal surface was strong with ultrasound through XPS results. The oxide on low rank coal/oxidized coal surface is firstly removed by ultrasound in the process of ultrasound treatment, the new surface is secondly reoxidized through ultrasound until the oxide is removed. However, the oxide can be removed in a short time of ultrasound treatment due to the coking coal surface with less oxide compared with low rank coal/oxidized coal, and then the new surface produced by ultrasound can be reoxidized through ultrasound.

Ultrasound were prone to the cavitation in water, which in turn produces cavitation bubbles, some of which may adhere to the coal surface, and some cavitation bubbles may aggregate or merge or even rupture. On the one hand, shock waves can clean the pollutants on the coal surface, on the other hand, they can clean the oxides on the coal surface. However, the rupture of cavitation bubble can also lead to the generation of $\bullet \mathrm{OH}$ and $\bullet \mathbf{H}$ through thermal decomposition [27]. It can be inferred from XPS results that $\bullet \mathrm{OH}$ and $\bullet \mathrm{H}$ free radicals can secondary reactions to produce $\mathrm{H}_{2} \mathrm{O}_{2}[12]$.

$$
\begin{aligned}
& \mathrm{H}_{2} \mathrm{O} \rightarrow \bullet \mathrm{H}+\bullet \text { OH } \\
& \bullet \mathrm{H}+\mathrm{O}_{2} \rightarrow \bullet \mathrm{HO}_{2} \\
& \text { • } \mathrm{HO}_{2}+\bullet \mathrm{HO}_{2} \rightarrow \mathrm{H}_{2} \mathrm{O}_{2}+\mathrm{O}_{2} \uparrow \\
& \text { • } \mathrm{OH}+\bullet \cdot \mathrm{OH} \rightarrow \mathrm{H}_{2} \mathrm{O}_{2}
\end{aligned}
$$

- $\mathrm{OH}$ and $\mathrm{H}_{2} \mathrm{O}_{2}$ had strong oxidation ability and reactivity. Which can oxidize the coal surface under ultrasound treatment [14]. Ultrasound oxidation inevitably leaded to an increase in the oxygen-containing functional groups on the coal surface, which ultimately leads to a slight decrease in the coal surface hydrophobicity. Combined with the flotation results in Figure 6, the yield of USF clean coal decreased slightly, which indicated that the oxidation of coal surface by ultrasound cavitation could eventually lead to the decrease of clean coal yield, but this decrease can be ignored. However, USF had a higher combustible recovery rate than $\mathrm{CF}$ as shown in Figure 7. The advantage was that it has a good influence on the float of coarse low-ash coal and the reduction of clean coking coal ash content. It showed that the negative impact of ultrasound on reducing the coal surface hydrophobicity was much less than the positive effect of ultrasound on the flotation selectivity.

\subsection{Flotation Results}

Figure 6 showed the cumulative yield of clean coal by USF was slightly higher than the CF at first stage of 30s. In the 30s-180s period, the CF cumulative clean coal yield was slightly higher than the USF. Since during the 10s aeration, the USF caused the coarse coal to float into the froth layer, resulting in a higher clean coal yield than CF. The clean coal yield was slightly decreased in the USF compared with that in the CF because the recovery of fine slime was reduced in USF. After adding ultrasound, the flotation of clean coal ash content was reduced by about $2 \%$ compared with the CF. Because of the physical cleaning action of ultrasound, which reduced the high-ash slime coated on the coal, and enhanced the selectivity of coking coal flotation.

To clearly show the difference in the efficiency of two flotation methods, the combustible recovery rate was computed and the results were showed in Figure 7 . The combustible recovery rate of USF was greater than that of CF. It showed that the selectivity of USF was better than that of CF. USF is beneficial to reducing the high-ash fine slime coated on the clean coal surface, so it enhances the selectivity of coking coal flotation. 


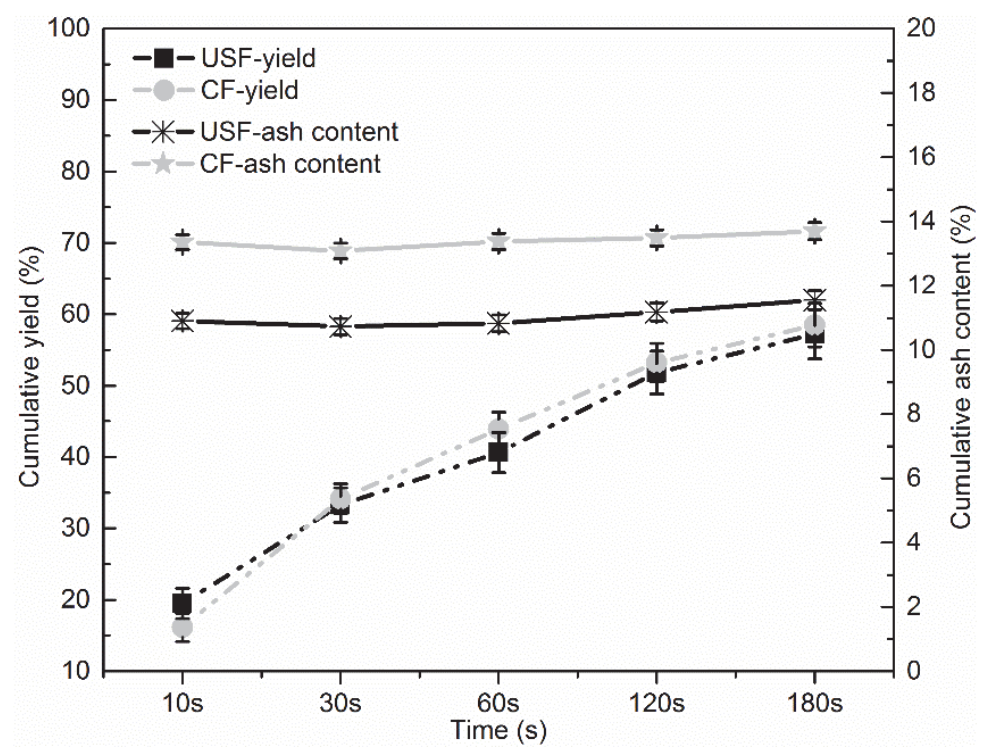

Figure 6. Results of flotation rate experiment

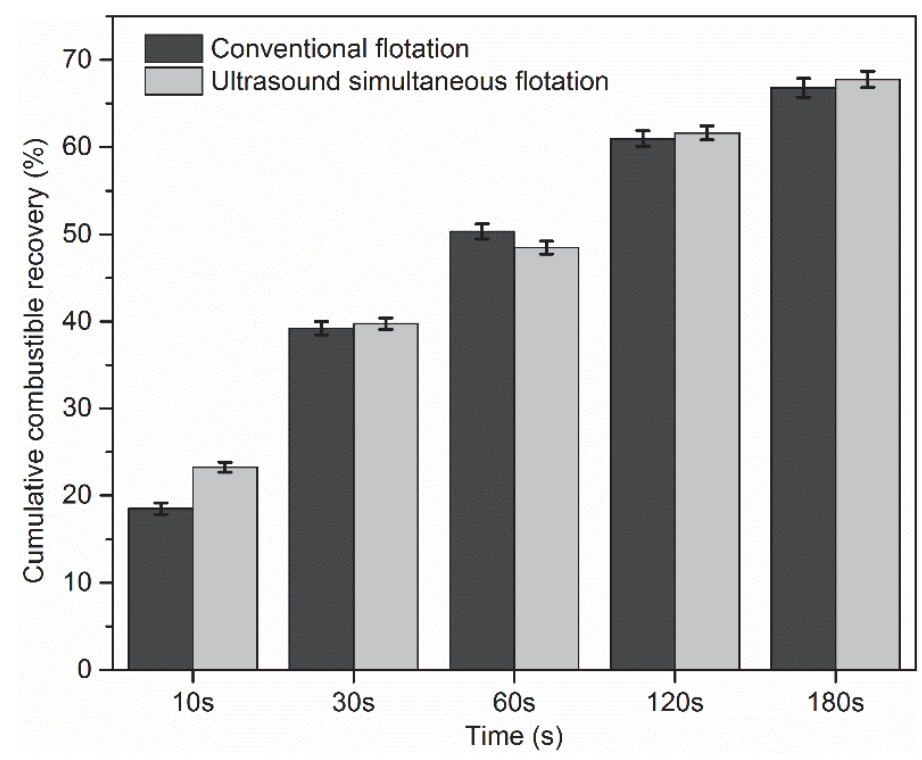

Figure 7. Cumulative combustible recovery rate in different time under $\mathrm{CF}$ and USF

\section{Conclusion}

In this paper, the recovery of coking coal by CF and USF was compared. It was found that the ultrasound cleaning the coal surface and reducing the high-ash fine slime coated on coal surface. The ultrasound promoted the recovery of coarse coal particles. Therefore, USF helps to enhance the coking coal flotation and reduce the clean coal ash content. In addition, the ultrasound can oxidize coking coal surface slightly, increase the content of oxygen-bearing functional groups on the coking coal surface, thereby reducing the hydrophobicity of coal surface. The negative impact of ultrasound on reducing the coal surface hydrophobicity was much less than the positive impact on the flotation selectivity. Therefore, the USF benefited the flotation of coking coal if a lower clean coal ash was required in coal flotation industry. 
Acknowledgements. This research was supported by the Fundamental Research Funds for the Central Universities (2017CXNL04). The authors would like to thank the Advanced Analysis and Computation Center of China University of Mining and Technology for their technical support.

\section{References}

1. Burmistrz P, Kogut K, Marczak M, Zwoździak J, "Lignites and subbituminous coals combustion in polish power plants as a source of anthropogenic mercury emission," Fuel Processing Technology, vol. 152, pp. 250-258, 2016.

2. Burmistrz P, Chmielniak T, Czepirski L, Gazda-Grzywacz M, "Carbon footprint of the hydrogen production process utilizing subbituminous coal and lignite gasification," Journal of Cleaner Production, vol. 139, pp. 858-865, 2016.

3. Laskowski JS, "Coal preparation," Developments in Mineral Processing, vol. 14, pp. 1-8, 2001.

4. Farrokhpay S, "The significance of froth stability in mineral flotation-a review," Advances in Colloid and Interface Science, vol. 166, no. 1-2, pp. 1-7, 2011.

5. Wen B, Xia W, Sokolovic JM, "Recent advances in effective collectors for enhancing the flotation of low rank/oxidized coals," Powder Technology, vol. 319, pp. 1-11, 2017.

6. Ni C, Bu X, Xia W, Peng Y, Xie G, "Effect of slimes on the flotation recovery and kinetics of coal particles," Fuel, vol. 220, pp. 159-166, 2018.

7. Ni C, Bu X, Xia W, Peng Y, Yu H, Xie G, "Observing slime-coating of fine minerals on the lump coal surface using particle vision and measurement," Powder Technology, vol. 339, pp. 434-439, 2018.

8. Xia W, Li Y, Nguyen AV, "Improving coal flotation using the mixture of candle soot and hydrocarbon oil as a novel flotation collector," Journal of Cleaner Production, vol. 195, pp. 1183-1189, 2018.

9. Li Y, Xia W, Zhang N, "Efficiency and mechanism analysis of the flotation of anthracite coal using soybean oil as an alternative sustainable collector," Energy Sources, Part A: Recovery, Utilization, and Environmental Effects, pp. 1-8, 2019.

10. Tan J, Long L, Xia W, Xie G, "The effect of different flotation operating parameters on the froth properties and their relation to clean coal ash content," Separation Science \&3 Technology, vol. 53, no. 2, pp. 1-11, 2018.

11. Chao N, Ma G, Xia W, Peng Y, Sha J, Xie G, "Influence of inclined plates in the froth zone on the flotation performance of a flotation column," International Journal of Coal Preparation \& Utilization, vol. 39, no. 3, pp. 132-144, 2017.

12. Xu M, Xing Y, Gui X, Cao Y, Wang L, "Effect of ultrasonic pretreatment on oxidized coal flotation," Energy 86 Fuels, vol. 31, no. 12, pp. 14367-14373, 2017.

13. Mao Y, Peng Y, Bu X, Xie G, Wu E, Xia W, "Effect of ultrasound on the true flotation of lignite and its entrainment behavior," Energy Sources Part A Recovery Utilization $\&$ Environmental Effects, vol. 40, no. 5, pp. 1-11, 2018.

14. Kang WZ, Xun HX, Chen JT, "Study of enhanced fine coal de-sulphurization and de-ashing by ultrasonic flotation," Journal of China University of Mining \& Technology, vol. 17, no. 3, pp. 358-362, 2007.

15. Ozkan SG, "Effects of simultaneous ultrasonic treatment on flotation of hard coal slimes," Fuel, vol. 93, pp. 576$580,2012$.

16. Mao Y, Xie G, Liang L, Xia W, Peng Y, "Effects of ultrasonic treatment on the particle size, shape and ash content of fine coal," Physicochemical Problems of Mineral Processing, vol. 55, no. 3, pp. 679-688, 2019.

17. Chen S, Tao X, Tang L, Dong F, Gui D, "Application of ultrasonic pretreatment for coking coal flotation and its mechanism," International Journal of Coal Preparation and Utilization, pp. 1-13, 2019.

18. Chao N, Xie G, Jin M, Peng Y, Xia W, "The difference in flotation kinetics of various size fractions of bituminous coal between rougher and cleaner flotation processes," Powder Technology, vol. 292, no.pp. 210-216, 2016.

19. Chao N, Bu X, Xia W, Peng Y, Xie G, "Effect of slimes on the flotation recovery and kinetics of coal particles," Fuel, vol. 220, pp. 159-166, 2018.

20. Yuqiang M, Wencheng X, "Discussion on ultrasonic enhanced lignite flotation and its action mechanism," Journal of China Coal Society, vol. 42, no. 11, pp. 3006-3013, 2017.

21. Mao Y, Chen Y, Bu X, Xie G, "Effects of $20 \mathrm{kHz}$ ultrasound on coal flotation: the roles of cavitation and acoustic radiation force," Fuel, vol. 256, pp. 115938-115945, 2019.

22. Jiakun T, The relation between flotation froth property and clean coal ash content. China University of Mining 
and Technology, 2018. (in Chinese)

23. Grzybek T, Pietrzak R, Wachowska H, "X-ray photoelectron spectroscopy study of oxidized coals with different sulphur content," Fuel Processing Technology, vol. 77, no. 1, pp. 1-7, 2002.

24. Niu C, Xia W, Xie G, "Effect of low-temperature pyrolysis on surface properties of sub-bituminous coal sample and its relationship to flotation response," Fuel, vol. 208, pp. 469-475, 2017.

25. Pietrzak R, Grzybek T, Wachowska H, "Xps study of pyrite-free coals subjected to different oxidizing agents," Fuel, vol. 86, no. 16, pp. 2616-2624, 2007.

26. Bo W, Peng Y, Vink S, "Diagnosis of the surface chemistry effects on fine coal flotation using saline water," Energy E Fuels, vol. 27, no. 8, pp. 4869-4874, 2013.

27. Suslick KS, "Sonochemistry," Science, vol. 247, no. 49, pp. 1439-1445, 1990. 